\title{
Identification of a novel mutation of NOG in family with proximal symphalangism and early genetic counseling
}

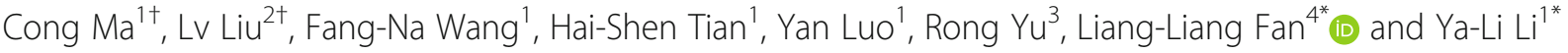

\begin{abstract}
Background: Proximal symphalangism is a rare disease with multiple phenotypes including reduced proximal interphalangeal joint space, symphalangism of the 4th and/or 5th finger, as well as hearing loss. At present, at least two types of proximal symphalangism have been identified in the clinic. One is proximal symphalangism- $1 \mathrm{~A}$ (SYM1A), which is caused by genetic variants in Noggin (NOG), another is proximal symphalangism-1B (SYM1B), which is resulted from Growth Differentiation Factor 5 (GDF5) mutations.

Case presentation: Here, we reported a Chinese family with symphalangism of the 4th and/or 5th finger and moderate deafness. The proband was a 13-year-old girl with normal intelligence but symphalangism of the 4th finger in the left hand and moderate deafness. Hearing testing and inner ear CT scan suggested that the proband suffered from structural deafness. Family history investigation found that her father (II-3) and grandmother (I-2) also suffered from hearing loss and symphalangism. Target sequencing identified a novel heterozygous NOG mutation, c.690C > G/p.C230W, which was the genetic lesion of the affected family. Bioinformatics analysis and public databases filtering further confirmed the pathogenicity of the novel mutation. Furthermore, we assisted the family to deliver a baby girl who did not carry the mutation by genetic counseling and prenatal diagnosis using amniotic fluid DNA sequencing.
\end{abstract}

Conclusion: In this study, we identified a novel NOG mutation (c.690C > G/p.C230W) by target sequencing and helped the family to deliver a baby who did not carry the mutation. Our study expanded the spectrum of NOG mutations and contributed to genetic diagnosis and counseling of families with SYM1A.

Keywords: Proximal symphalangism, Deafness, NOG mutation, Prenatal diagnosis

\section{Background}

Proximal symphalangism is a rare genetic disorder of congenital limb malformation, characterized by ankylosis of the proximal interphalangeal joints, carpal and tarsal bone fusion, and, in some cases, conductive deafness and premature ovarian failure $[1,2]$. The typical features of proximal symphalangism are reduced proximal interphalangeal joint space, symphalangism of the 4th and/or 5th finger [3, 4]. As early as in 1916, Cushing has

\footnotetext{
* Correspondence: swfanliangliang@csu.edu.cn; ly18703@sina.com

${ }^{+}$Cong Ma and Lv Liu contributed equally to this work.

${ }^{4}$ Department of Cell Biology, The School of Life Sciences, Central South

University, Changsha 410011, Hunan, China

'Departments of Reproductive Genetics, HeBei General Hospital,

ShiliaZhuang 050051, China

Full list of author information is available at the end of the article
}

described an American family with ankylosis of the proximal interphalangeal joints, and he named this heterozygote autosomal dominant disease as symphalangism [5].

At present, there are two types of diseases in the proximal symphalangism family: (1) Proximal symphalangism-1A (SYM1A, OMIM \# 185800), which iss caused by genetic variants in Noggin (NOG) [6, 7]; (2) Proximal symphalangism-1B (SYM1B), which is resulted from Growth Differentiation Factor 5 (GDF5) mutations [8, 9]. In addition, some other diseases may be also related to proximal symphalangism, such as tarsal-carpal coalition syndrome, multiple synostoses syndrome, and brachydactyly, etc. [10, 11].

In this study, we employed target sequencing to explore the genetic lesion of a Chinese family with symphalangism of the 4th and/or 5th finger and moderate 
deafness. A novel mutation (c.690C > G/p.C230W) of NOG was identified in all affected individuals in this family. Furthermore, after genetic counseling and prenatal diagnosis with us, the mother successfully delivered a baby girl who did not carry the mutation.

\section{Case presentation}

A family from North of China (Hebei Province) with eight members across three generations participated in the study (Fig. 1a). The proband (III-2) was a 13-yearold girl with normal intelligence but symphalangism of the 4th finger in the left hand (Fig. 1b) and moderate deafness (Fig. 1c). Inner ear CT scan found abnormal inner ear structure (cochlear hypoplasia) and abnormal calcification (inner ear bone thickening and increased density) (Fig. 1d). Family history investigation found that her father (II-3) and grandmother (I-2) also suffered from hearing loss and symphalangism (Fig. 1a, e). Her grandmother has died six years ago. Her father showed the symphalangism of the 4th finger in left hand (Fig. 1e, f). He had performed the vestibulotomy and recovered the hearing one year ago. They went to the Department of Reproductive Genetics, HeBei General Hospital because the mother was pregnant with the second baby. They wanted to detect whether the second baby was normal or not.

\section{Genetic analysis}

We selected the proband's genomic DNA to perform the target sequencing to detect the disease-causing mutations by Sinopath Diagnosis Company (Beijing, China). Target sequencing yielded $3.71 \mathrm{~Gb}$ of data with $99.088 \%$ coverage of the target region and $97.530 \%$ of the target covered over 10x. After filtering dbSNP132, 1000G, EXAC, and GenomAD database (MAF $<0.01$ ), only 12 mutation were left. We then conducted the cosegregation analysis by Sanger sequencing and only seven variants were exist in affected individuals and were absent in healthy members (Table 1). We further performed the bioinformatics analysis including MutationTaster, SIFT, Polyphen-2, PANTHER, ToppGene function analysis, OMIM clinical phenotype analysis and ACMG classification (Table 1), we highly suspected the novel mutation (c.690C > G/p.C230W) of NOG, belonging to PM1 and PM2 in ACMG guidelines [12], was responsible for the family with SMY1A. This mutation resulted in a substitution of in polar amino acid cysteine by nonpolar amino acid tryptophan in the codon 230 of exon 1 of NOG gene, and was not presented in our 200 control cohorts. Noggin amino acid sequence alignment analysis suggested that this mutation was located in a highly evolutionarily conserved site (Fig. 2b). In addition, we also constructed a part model of the Noggin protein using SWISS-MODEL (https://swissmodel.expasy.org)
(Fig. 2c) and, after applying SDM software (http://marid. bioc.cam.ac.uk/sdm2/prediction) to analyze the structure, it was found that this novel mutation might increase the solvent accessibility (WT:16.9\% and Mutant: $39.9 \%$ ) and reduce the stability of the Noggin protein.

\section{Prenatal diagnosis}

When the parents came to our hospital, the mother has been pregnant with the second baby for 17 weeks and they wanted to have a healthy baby. According to ACMG classification, the novel mutation (c.690C > G/ p.C230W) of NOG belongs to PM1 and PM2. Simultaneously, target sequencing only identified this mutation as a pathogenic variant. So, we highly believed the novel mutation (c.690C > G/p.C230W) of NOG was the genetic lesion of the family with proximal symphalangism and hearing loss. We then performed the Sanger sequencing of amniotic fluid DNA to detect the mutation, fortunately, the results showed a normal allele of the second baby. And 22 weeks later, the mother delivered a $3.4-\mathrm{kg}$ healthy girl (Fig. 2d).

\section{Discussion}

The human NOG gene encoding Noggin protein is located on chromosome 17q22, and it consists of one exon, spanning approximately 1.9 kilobases (kb) [6]. Noggin protein is involved in the development of many body tissues, including nerve tissue, muscles, and bones and the role of Noggin in bone development makes it significant for proper joint formation [13]. According to previous researches, Noggin protein can interact with bone morphogenetic proteins (BMPs) and regulate the development of bone and other tissues [14]. In detail, the Noggin protein regulates the activity of BMPs by binding to them and blocking them from attaching to the downstream receptor, which results in a decrease in BMP signaling [15]. In our research, the novel mutation (c.690C > G/p.C230W) of NOG can increase the solvent accessibility and reduce the stability of the Noggin, which may active the BMP signal pathway and lead to bone diseases.

In 1999, five NOG mutations were identified in unrelated families with symphalangism (SYM1A) and a de novo mutation in a patient with unaffected parents [6]. Interestingly, a wide variety of bone development anomalies, including tarsal/carpal coalition syndrome [10], brachydactyly [16], multiple synostoses syndrome [17], Stapes ankylosis with broad thumbs and toes [18], have been reported in patients with NOG mutations. Similar observations were also reported in the families even with the same mutation $[16,19]$. Therefore, the pleiotropic types of bone diseases and significant genetic heterogeneity make it difficult to be diagnosed. We summarized the previous reports and found that approximately 57 


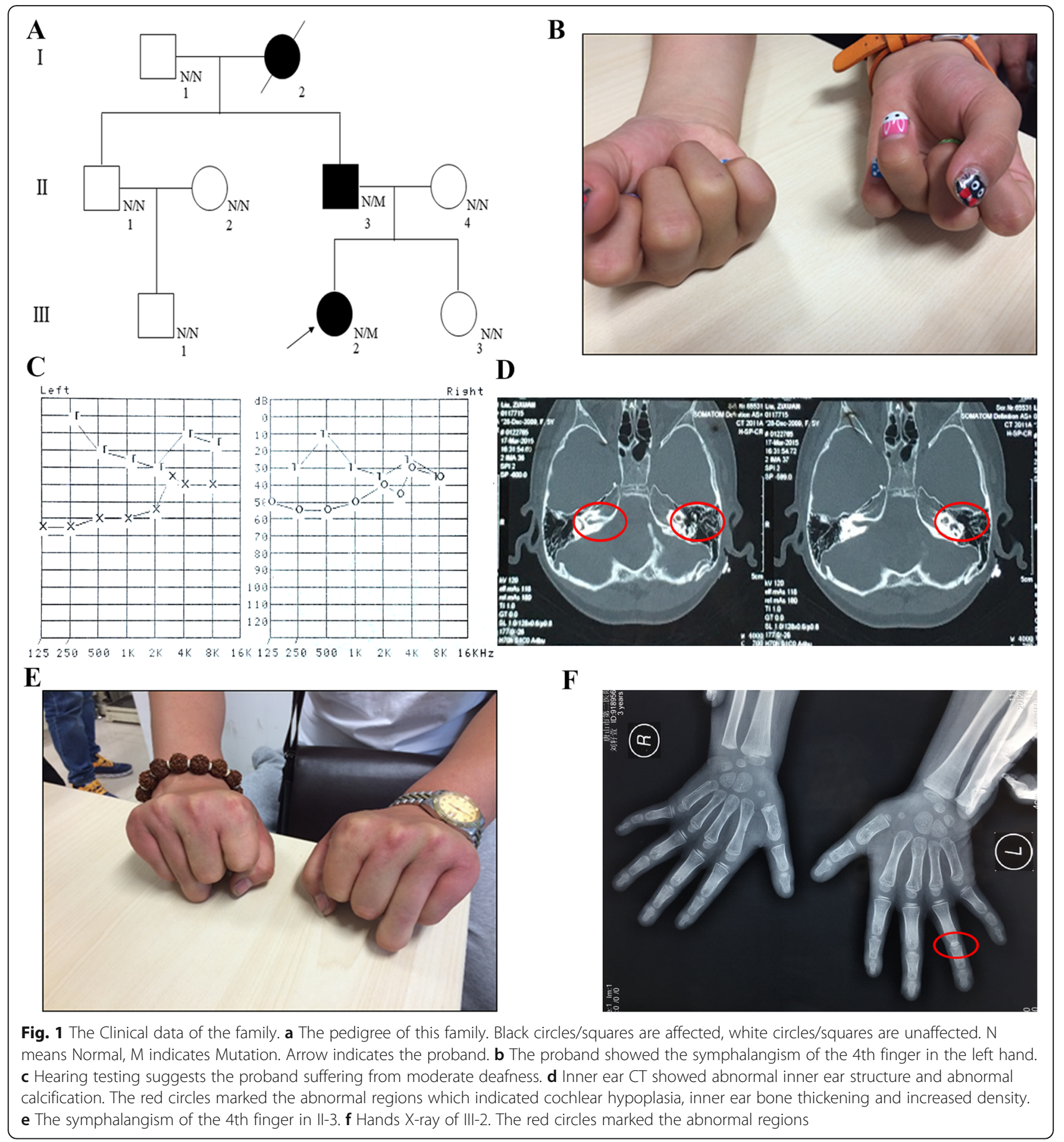

mutations (60 patients) of NOG have been identified in different types of disorders (Table 2).

In this study, a family with symphalangism and moderate deafness was investigated by target sequencing. Genetic analysis found a novel mutation (c.690C > G/p.C230W) of NOG in two affected members. Of note, both of two patients with p.C230W in the family were associated with hearing loss. To date, 29 mutations have been reported in symphalangism patients related to deafness (Table 2) [11].
And the mutation p.C230W was the fifth report related to NOG mutation, although some Chinese journals have also published some reported mutations. Meanwhile, this difference also suggested that there were still a lot of novel mutations need to discovery in Chinese population.

The p.C230W mutation disrupts the cysteine knot motif of the C-terminal domain of Noggin (amino acids 155-232), which contains a series of nine cysteine residues and was shown to target the molecule 
Table 1 The mutations list after data filtering and co-segregation analysis

\begin{tabular}{|c|c|c|c|c|c|c|c|c|c|c|c|c|}
\hline $\mathrm{CHR}$ & POS & $\mathrm{RB}$ & $A B$ & Gene & Mutation & SIFT & $\begin{array}{l}\text { PolyPhen- } \\
2\end{array}$ & MutationTaster & PANTHER & $\begin{array}{l}\text { OMIM clinical } \\
\text { phenotype }\end{array}$ & ToppGene function & $\begin{array}{l}\text { ACMG } \\
\text { classification }\end{array}$ \\
\hline 1 & $\begin{array}{l}45, \\
481 \\
060\end{array}$ & $C$ & T & UROD & $\begin{array}{l}\text { NM_000374: } \\
\text { c.994C > T, } \\
\text { p.R332C }\end{array}$ & $0, \mathrm{D}$ & $0.94, \mathrm{D}$ & $0.99, \mathrm{D}$ & - & $\begin{array}{l}\text { AD or AR: } \\
\text { Porphyria } \\
\text { cutanea tarda }\end{array}$ & $\begin{array}{l}\text { heme biosynthetic } \\
\text { process }\end{array}$ & BP5 \\
\hline 2 & $\begin{array}{l}149, \\
216, \\
410\end{array}$ & G & A & MBD5 & $\begin{array}{l}\text { NM_018328: } \\
\text { c.83G > A, } \\
\text { p.R28H }\end{array}$ & $0, \mathrm{D}$ & $0.99, \mathrm{D}$ & $0.99, \mathrm{D}$ & $P$ & $\begin{array}{l}\text { AD: Mental } \\
\text { retardation }\end{array}$ & $\begin{array}{l}\text { response to growth } \\
\text { hormone }\end{array}$ & BP5 \\
\hline 2 & $\begin{array}{l}189, \\
953 \\
479\end{array}$ & G & T & COL5A2 & $\begin{array}{l}\text { NM_000393: } \\
\text { c.587G > T, } \\
\text { p.A196D }\end{array}$ & $\begin{array}{l}0.29, \\
T\end{array}$ & $0.98, \mathrm{D}$ & $0.99, \mathrm{D}$ & - & $\begin{array}{l}\text { AD: Ehlers- } \\
\text { Danlos } \\
\text { syndrome }\end{array}$ & $\begin{array}{l}\text { regulation of } \\
\text { endodermal cell } \\
\text { differentiation }\end{array}$ & $\mathrm{BP} 4, \mathrm{BP} 5$ \\
\hline 3 & $\begin{array}{l}38, \\
674 \\
642\end{array}$ & G & A & SCN5A & $\begin{array}{l}\text { NM_198056: } \\
157 G>A \\
\text { p.R53W }\end{array}$ & $0, D$ & $0.36, \mathrm{~B}$ & $0.95, \mathrm{D}$ & $P$ & $\begin{array}{l}\text { AD: Atrial } \\
\text { fibrillation }\end{array}$ & $\begin{array}{l}\text { voltage-gated sodium } \\
\text { channel activity }\end{array}$ & $\mathrm{BP} 4, \mathrm{BP} 5$ \\
\hline 3 & $\begin{array}{l}184 \\
953 \\
112\end{array}$ & G & A & EHHADH & $\begin{array}{l}\text { NM_001966: } \\
\text { c.317G >A } \\
\text { p.A106V }\end{array}$ & $0, \mathrm{D}$ & $0.99, \mathrm{D}$ & $0.99, \mathrm{D}$ & $P$ & $\begin{array}{l}\text { AD: Fanconi } \\
\text { renotubular } \\
\text { syndrome }\end{array}$ & peroxisomal transport & BP5 \\
\hline 17 & $\begin{array}{l}48, \\
701 \\
856\end{array}$ & G & A & $\begin{array}{l}\text { CACN } \\
\text { A1G }\end{array}$ & $\begin{array}{l}\text { NM_018896: } \\
\text { c.6365G >A, } \\
\text { p.R2122H }\end{array}$ & $\begin{array}{l}0.04 \\
D\end{array}$ & $0.01, \mathrm{~B}$ & $0.8, \mathrm{D}$ & $P$ & $\begin{array}{l}\text { AD: } \\
\text { Spinocerebellar } \\
\text { ataxia }\end{array}$ & $\begin{array}{l}\text { voltage-gated calcium } \\
\text { channel }\end{array}$ & BP4, BP5 \\
\hline 17 & $\begin{array}{l}54 \\
672 \\
274\end{array}$ & C & G & NOG & $\begin{array}{l}\text { NM_005450: } \\
\text { c.690C > G, } \\
\text { p.C230W }\end{array}$ & $0, \mathrm{D}$ & $0.99, \mathrm{D}$ & $0.99, \mathrm{D}$ & D & $\begin{array}{l}\text { AD: } \\
\text { Symphalangism } \\
\text { proximal }\end{array}$ & $\begin{array}{l}\text { fibroblast growth } \\
\text { factor receptor } \\
\text { signaling pathway }\end{array}$ & PM1, PM2 \\
\hline
\end{tabular}

CHR Chromosome, $P O S$ position, $R B$ reference sequence base, $A B$ alternative base identified, $D$ damaging, $P$ probably damaging, $B$ Benign, $T$ Tolerated, $A R$ autosomal recessive, $A D$ autosomal dominant, $B P$ Benign Supporting, $P M$ Pathogenicity Moderate

to a specific receptor protein $[20,21]$. The similar mutations (p.C228G, p.C228S, p.C230Y and p.C232W) have been identified in patients with symphalangism and hearing loss, which indicated that mutations in cysteine residues may be related to abnormal development of auditory ossicles and hearing loss [19, 22-24].
In clinical genetics, the aim of mutation detection is to make contributions to genetic diagnosis and counseling. In this study, we identified the genetic lesion of the family by target sequencing. All the filtered data were shown in Table 1 . We not only performed the informatics analysis of the novel mutation by multi-different algorithm based bioinformatics programs, but also followed the

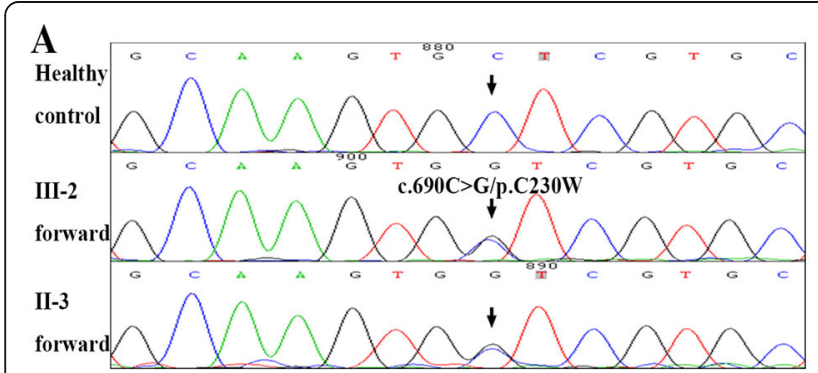

B

\begin{tabular}{|c|c|c|c|c|c|c|c|c|c|c|c|c|c|}
\hline \multirow[b]{2}{*}{ Human } & \multirow[b]{2}{*}{ I } & \multirow[b]{2}{*}{ Q } & \multirow[b]{2}{*}{$\mathrm{Y}$} & \multirow[b]{2}{*}{$\mathrm{P}$} & \multirow[b]{2}{*}{ I } & \multirow[b]{2}{*}{ I } & \multirow[b]{2}{*}{$\mathrm{S}$} & \multirow[b]{2}{*}{$\mathrm{E}$} & \multicolumn{5}{|c|}{ p. $\underset{\downarrow}{C 230}$} \\
\hline & & & & & & & & & $\mathrm{C}$ & $\mathrm{K}$ & $\mathrm{C}$ & $\mathrm{S}$ & $\mathrm{C}$ \\
\hline Ptroglodytes & I & Q & $\mathrm{Y}$ & $\mathrm{P}$ & I & I & $\mathrm{S}$ & $\mathrm{E}$ & $\mathrm{C}$ & $\mathrm{K}$ & $\mathrm{C}$ & $\mathrm{S}$ & $\mathrm{C}$ \\
\hline Mmulatta & I & Q & $\mathrm{Y}$ & $\mathrm{P}$ & I & I & $\mathrm{S}$ & $\mathrm{E}$ & $\mathrm{C}$ & $\mathrm{K}$ & $\mathrm{C}$ & $\mathrm{S}$ & $\mathrm{C}$ \\
\hline Mmusculus & I & Q & $\mathrm{Y}$ & $\mathrm{P}$ & I & I & $\mathrm{S}$ & $\mathrm{E}$ & $\mathrm{C}$ & $\mathrm{K}$ & $\mathrm{C}$ & $\mathrm{S}$ & $\mathrm{C}$ \\
\hline Ggallus & I & Q & $\mathrm{Y}$ & $\mathrm{P}$ & I & I & A & $\mathrm{E}$ & $\mathrm{C}$ & $\mathrm{K}$ & $\mathrm{C}$ & $\mathrm{S}$ & $\mathrm{C}$ \\
\hline Trubripes & M & Q & $\mathrm{Y}$ & $\mathrm{P}$ & V & I & $\mathrm{T}$ & $\mathrm{D}$ & $\mathrm{C}$ & $\mathrm{K}$ & C & $\mathrm{S}$ & $\mathrm{C}$ \\
\hline Drerio & $\mathrm{V}$ & Q & $\mathrm{Y}$ & $\mathrm{P}$ & $\mathrm{V}$ & I & $\mathrm{S}$ & $E$ & $\mathrm{C}$ & $\mathrm{K}$ & $\mathrm{C}$ & $\mathrm{S}$ & $\mathrm{C}$ \\
\hline Xtropicalis & I & Q & $\mathrm{Y}$ & $\mathrm{P}$ & V & I & $\mathrm{S}$ & $\mathrm{E}$ & $\mathrm{C}$ & $\mathrm{K}$ & $\mathrm{C}$ & $\mathrm{S}$ & $\mathrm{C}$ \\
\hline
\end{tabular}

C

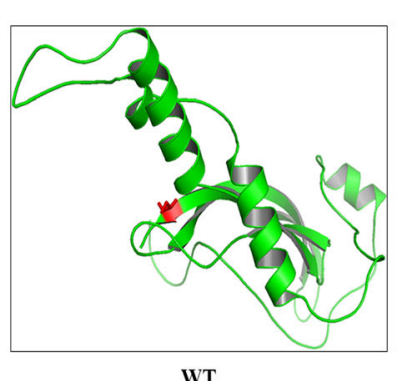

WT

D

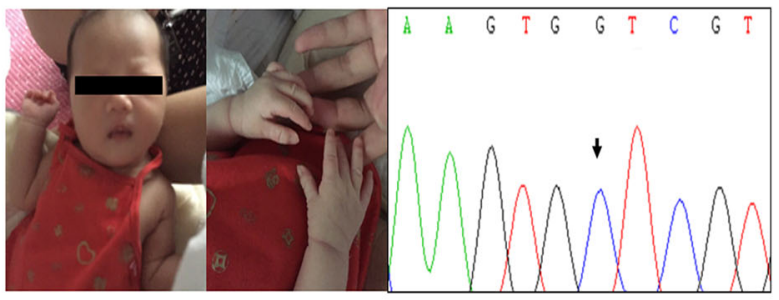

Fig. 2 Genetic analysis of the family. a Sanger DNA sequencing chromatogram demonstrates the heterozygosity for a NOG mutation (c.690C > G/ p.C230W). $\mathbf{b}$ Analysis of the mutation and protein domains of Noggin. The C230 affected amino acid locates in the highly conserved amino acid region in different mammals (from Ensembl). The black arrow and red words show the C230 site. c Swiss-model analyzed the Noggin structures of WT and Mutated (p.C230W). d The healthy hands of III-3 and normal sequences of amniotic fluid DNA 


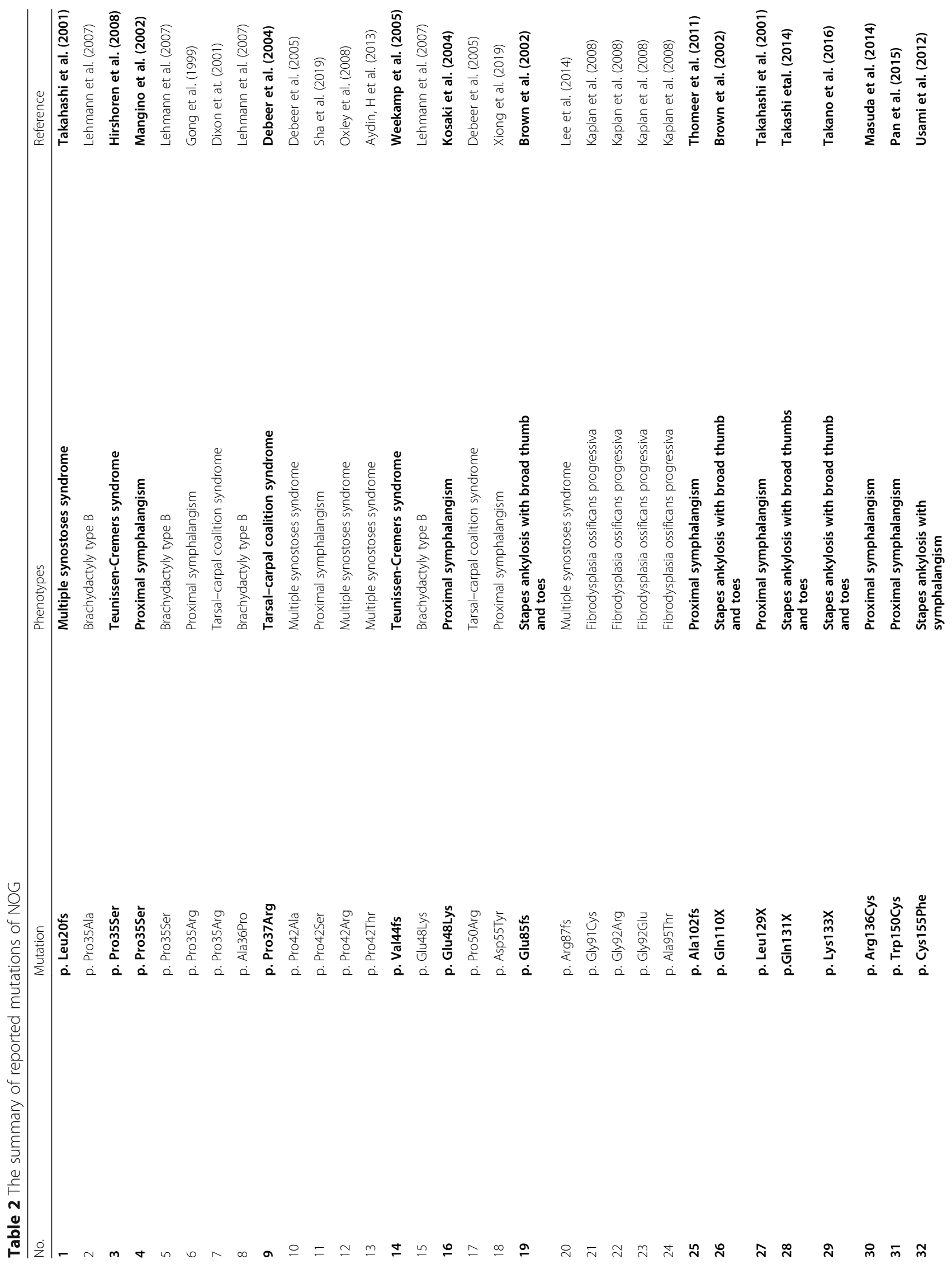




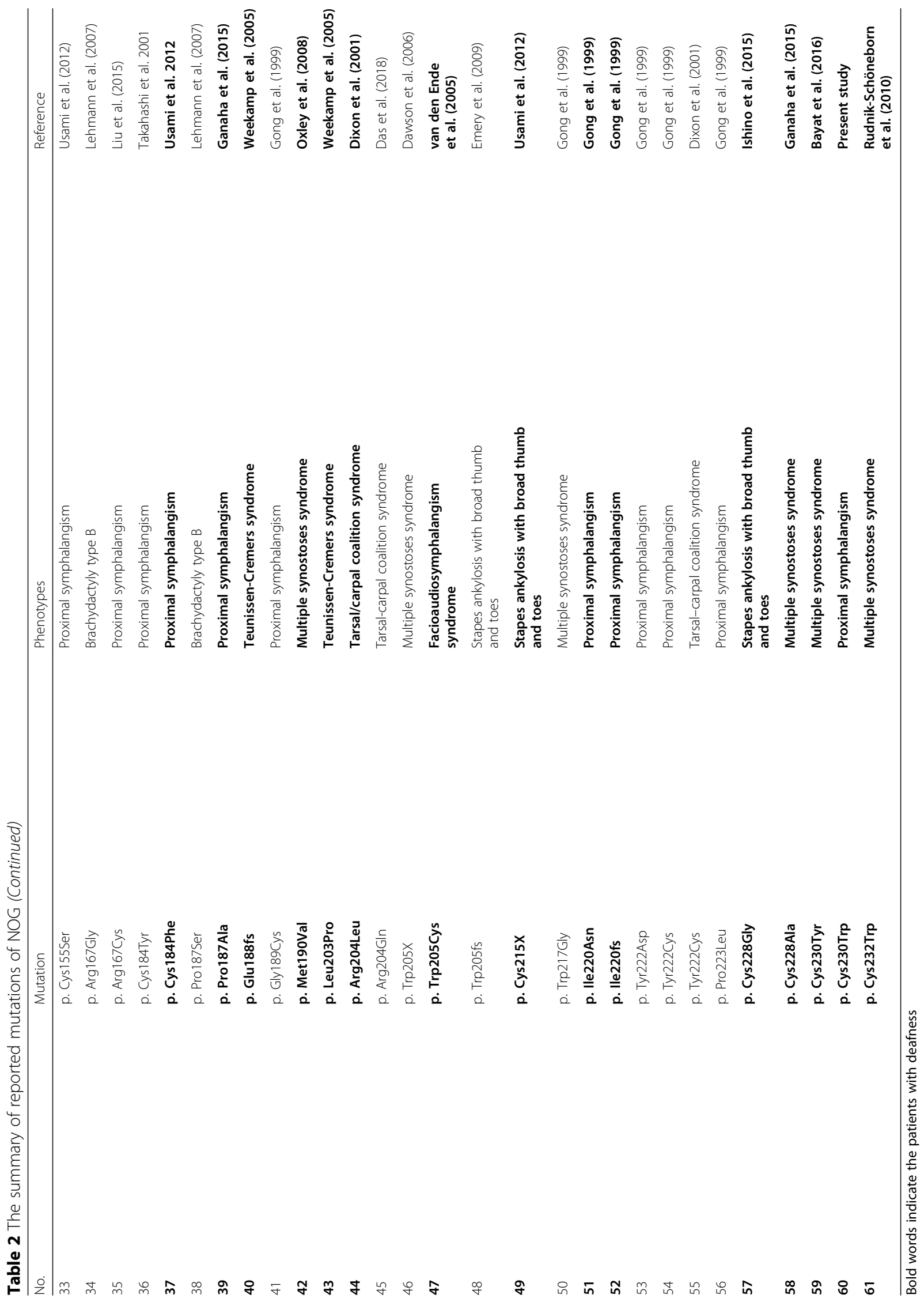


ACMG guidelines to estimate the pathogenicity of the novel mutation strictly (PM1 and PM2). Finally, we highly believed that the novel mutation (p.C230W) of NOG may be the genetic lesion of the family. We then assisted the family to get a healthy baby by amniotic fluid DNA sequencing referring to other people's research [25]. Prenatal diagnosis not only helped the patient to delivery healthy baby and improved the population quality but also relieved psychological and financial stress [26]. Our study provided a successful example for genetic counseling and prenatal diagnosis of patients with SYM1A.

\section{Conclusions}

We reported a novel NOG mutation (c.690C $>$ G/ p.C230W) in a three-generation family with SYM1A. And we helped them delivery a girl baby who did not carry the mutation by genetic counseling and prenatal diagnosis. Our study not only presented the important role of NOG in proximal symphalangism and deafness but also expanded the spectrum of NOG mutations and contributed to genetic diagnosis and counseling of families with SYM1A.

\section{Abbreviations}

BMPs: Bone morphogenetic proteins; GDF5: Growth Differentiation Factor 5; kb: Kilobases; NOG: Noggin; SYM1A: proximal symphalangism-1A;

SYM1B: proximal symphalangism-1B

\section{Acknowledgements}

We thank all subjects for participating in this study.

\section{Authors' contributions}

$C M$ and $L L$ carried out the sample collecting and genetic testing, F-N W, H$S T$ and $Y L$ collected the clinical data, $R Y$ performed the bioinformatics analysis, $Y-L L$ and $L-L F$ designed the project and wrote the manuscript, and $L-L$ $\mathrm{F}$ revised the manuscript. All authors read and approved the final manuscript.

\section{Funding \\ During the whole course of this study, the study design, data collection, data analysis, data interpretation and manuscript preparation were mainly supported by National Natural Science Foundation of China (81800220) and Hunan province Natural Science Foundation (2019JJ50890). Part of the data analysis, which is the prenatal diagnosis was supported by Hebei Science and Technology Plan Project (17277728D).}

\section{Availability of data and materials}

The datasets used and/or analyzed during the current study are available from the corresponding author on reasonable request.

\section{Ethics approval and consent to participate}

Written informed consent was obtained from each individual and the investigation was approved by the Institutional Review Board of HeBei General Hospital.

\section{Consent for publication}

Written consent was obtained from all the participants or their guardians for the publication of this study.

\section{Competing interests}

The authors declare that they have no competing interests.

\section{Author details}

${ }^{1}$ Departments of Reproductive Genetics, HeBei General Hospital, ShiJiaZhuang 050051, China. ${ }^{2}$ Department of Respiratory Medicine, Diagnosis and Treatment Center of Respiratory Disease, Diagnosis and Treatment Center of Respiratory Disease, the Second Xiangya Hospital of Central South University, Changsha 410011, Hunan, China. ${ }^{3}$ Departments of Anesthesiology, the Second Xiangya Hospital, Central South University, Changsha 410011, China. ${ }^{4}$ Department of Cell Biology, The School of Life Sciences, Central South University, Changsha 410011, Hunan, China.

Received: 16 May 2019 Accepted: 31 October 2019

Published online: 06 November 2019

\section{References}

1. Plett SK, Berdon WE, Cowles RA, Oklu R, Campbell JB. Cushing proximal symphalangism and the NOG and GDF5 genes. Pediatr Radiol. 2008;38(2): 209-15.

2. Kadi N, Tahiri L, Maziane M, Mernissi FZ, Harzy T. Proximal symphalangism and premature ovarian failure. Joint Bone Spine. 2012;79(1):83-4.

3. Pasha AS, Weimer M. Symphalangism. Arthritis Rheumatol. 2016;68(9):2327.

4. Cushing H. Hereditary anchylosis of the proximal phalangeal joints (symphalangism). Clin Orthop Relat Res. 1915;2002(401):4-5 discussion 4.

5. Cushing H. Hereditary Anchylosis of the proximal Phalan-Geal joints (Symphalangism). Genetics. 1916;1 (1):90-106.

6. Gong Y, Krakow D, Marcelino J, Wilkin D, Chitayat D, Babul-Hirji R, Hudgins $\mathrm{L}$, Cremers CW, Cremers FP, Brunner HG, et al. Heterozygous mutations in the gene encoding noggin affect human joint morphogenesis. Nat Genet. 1999;21(3):302-4.

7. Sha Y, Ma D, Zhang N, Wei X, Liu W, Wang X. Novel NOG (p.P42S) mutation causes proximal symphalangism in a four-generation Chinese family. BMC Med Genet. 2019;20(1):133.

8. Leonidou A, Irving M, Holden S, Katchburian M. Recurrent missense mutation of GDF5 (p.R438L) causes proximal symphalangism in a British family. World J Orthop. 2016;7(12):839-42.

9. Seemann P, Schwappacher R, Kjaer KW, Krakow D, Lehmann K, Dawson K, Stricker S, Pohl J, Ploger F, Staub E, et al. Activating and deactivating mutations in the receptor interaction site of GDF5 cause symphalangism or brachydactyly type A2. J Clin Invest. 2005;115(9):2373-81.

10. Das Bhowmik A, Salem Ramakumaran V, Dalal A. Tarsal-carpal coalition syndrome: report of a novel missense mutation in NOG gene and phenotypic delineation. Am J Med Genet A. 2018;176(1):219-24.

11. Takano K, Ogasawara N, Matsunaga T, Mutai H, Sakurai A, Ishikawa A, Himi T. A novel nonsense mutation in the NOG gene causes familial NOG-related symphalangism spectrum disorder. Hum Genome Var. 2016;3:16023.

12. Richards S, Aziz N, Bale S, Bick D, Das S, Gastier-Foster J, Grody WW, Hegde $\mathrm{M}$, Lyon E, Spector E, et al. Standards and guidelines for the interpretation of sequence variants: a joint consensus recommendation of the American College of Medical Genetics and Genomics and the Association for Molecular Pathology. Genet Med. 2015;17(5):405-24.

13. Marcelino J, Sciortino CM, Romero MF, Ulatowski LM, Ballock RT, Economides AN, Eimon PM, Harland RM, Warman ML. Human diseasecausing NOG missense mutations: effects on noggin secretion, dimer formation, and bone morphogenetic protein binding. Proc Natl Acad Sci U S A. 2001:98(20):11353-8

14. Schmidt-Bleek K, Willie BM, Schwabe P, Seemann P, Duda GN. BMPs in bone regeneration: less is more effective, a paradigm-shift. Cytokine Growth Factor Rev. 2016;27:141-8.

15. Wan DC, Pomerantz JH, Brunet LJ, Kim JB, Chou YF, Wu BM, Harland R, Blau HM, Longaker MT. Noggin suppression enhances in vitro osteogenesis and accelerates in vivo bone formation. J Biol Chem. 2007;282(36):26450-9.

16. Lehmann K, Seemann P, Silan F, Goecke TO, Irgang S, Kjaer KW, Kjaergaard S, Mahoney MJ, Morlot S, Reissner C, et al. A new subtype of brachydactyly type $B$ caused by point mutations in the bone morphogenetic protein antagonist NOGGIN. Am J Hum Genet. 2007;81(2):388-96.

17. Lee BH, Kim OH, Yoon HK, Kim JM, Park K, Yoo HW. Variable phenotypes of multiple synostosis syndrome in patients with novel NOG mutations. Joint Bone Spine. 2014;81(6):533-6.

18. Thomeer HG, Admiraal RJ, Hoefsloot L, Kunst HP, Cremers CW. Proximal symphalangism, hyperopia, conductive hearing impairment, and the NOG gene: 2 new mutations. Otology Neurotol. 2011;32(4):632-8. 
19. Ganaha A, Kaname T, Akazawa Y, Higa T, Shinjou A, Naritomi K, Suzuki M. Identification of two novel mutations in the NOG gene associated with congenital stapes ankylosis and symphalangism. J Hum Genet. 2015;60(1):27-34.

20. Groppe J, Greenwald J, Wiater E, Rodriguez-Leon J, Economides AN,

Kwiatkowski W, Affolter M, Vale WW, Izpisua Belmonte JC, Choe S. Structural basis of BMP signalling inhibition by the cystine knot protein noggin. Nature. 2002;420(6916):636-42.

21. Brown DJ, Kim TB, Petty EM, Downs CA, Martin DM, Strouse PJ, Moroi SE, Milunsky JM, Lesperance MM. Autosomal dominant stapes ankylosis with broad thumbs and toes, hyperopia, and skeletal anomalies is caused by heterozygous nonsense and frameshift mutations in NOG, the gene encoding noggin. Am J Hum Genet. 2002;71(3):618-24.

22. Rudnik-Schoneborn S, Takahashi T, Busse S, Schmidt T, Senderek J Eggermann T, Zerres K. Facioaudiosymphalangism syndrome and growth acceleration associated with a heterozygous NOG mutation. Am J Med Genet A. 2010;152A(6):1540-4.

23. Ishino T, Takeno S, Hirakawa K. Novel NOG mutation in Japanese patients with stapes ankylosis with broad thumbs and toes. Eur J Med Genet. 2015 58(9):427-32.

24. Bayat A, Fijalkowski I, Andersen T, Abdulmunem SA, van den Ende J, Van Hul W. Further delineation of facioaudiosymphalangism syndrome: description of a family with a novel NOG mutation and without hearing loss. Am J Med Genet A. 2016;170(6):1479-84.

25. Abou Tayoun AN, Spinner NB, Rehm HL, Green RC, Bianchi DW. Prenatal DNA sequencing: clinical, counseling, and diagnostic laboratory considerations. Prenat Diagn. 2018;38(1):26-32.

26. Vermeesch JR, Voet $T$, Devriendt K. Prenatal and pre-implantation genetic diagnosis. Nat Rev Genet. 2016;17(10):643-56.

\section{Publisher's Note}

Springer Nature remains neutral with regard to jurisdictional claims in published maps and institutional affiliations.

Ready to submit your research? Choose BMC and benefit from:

- fast, convenient online submission

- thorough peer review by experienced researchers in your field

- rapid publication on acceptance

- support for research data, including large and complex data types

- gold Open Access which fosters wider collaboration and increased citations

- maximum visibility for your research: over $100 \mathrm{M}$ website views per year

At $\mathrm{BMC}$, research is always in progress.

Learn more biomedcentral.com/submissions 